\title{
Cytokines and TLR agonists influence the expression of retention integrins CD49a, CD49b and CD103 by T cells
}

\author{
Marit M Melssen*, Ciara Hutchison, lleana S Mauldin, Timothy N Bullock, Craig L Slingluff \\ From 30th Annual Meeting and Associated Programs of the Society for Immunotherapy of Cancer \\ (SITC 2015) \\ National Harbor, MD, USA. 4-8 November 2015
}

$\mathrm{T}$ cell infiltration in the tumor microenvironment (TME) is positively correlated with survival. Infiltration is not a stable state, but a dynamic process of homing, infiltration, retention and survival. Every step in this process is crucial for the eventual tumor reactive activity of $\mathrm{T}$ cells. Our laboratory has previously shown a marked upregulation of retention integrins (RI) CD49a, CD49b and CD103 on tumor infiltrating lymphocytes (TIL) in melanoma. T cells in peripheral tissues expressing RI appear to have a cytotoxic phenotype and $\mathrm{RI}^{+} \mathrm{TIL}$ are associated with improved patient survival. Despite their importance in retention of tumor reactive TILs, little is known about pathways inducing RI expression, except that TGF $\beta$ induces CD103. We hypothesized that other cytokines, TLR agonists and $\mathrm{T}$ cell receptor (TCR) stimulation can induce RI expression by circulating $\mathrm{T}$ cells. PBMCs were grown in presence of cytokines after TCR stimulation and RI expression was evaluated by flow cytometry after 2-7 days. Both CD103 and CD49a are induced by TGF $\beta$, most strikingly on activated T cells. IL2 and IL10 also influence CD49a expression. CD49b expression is increased by IL2, IL4 and IL10, although this depends on $\mathrm{T}$ cell subset and activation state. TLR2, TLR6 and TLR7 agonists appear to induce $\mathrm{CD} 49 \mathrm{a}$ and $\mathrm{CD} 49 \mathrm{~b}$ as well. In addition we have found that IL2 and TGF $\beta$ upregulate RI expression on T cells with different proliferation rates and cytotoxic activity. In conclusion, above results support our hypothesis by showing that RI expression is tightly regulated by cytokine and TCR stimulation. Interestingly, the regulating factors have different effects among the RI and phenotype of RI+ $T$ cells. Which suggests a different role for each of the RI and a substantial contribution of the induction route in

University of Virginia, Charlottesville, VA, USA the determination of this role. Furthermore the cytokines found to be involved with RI expression are associated with either Th1, Th2 or Treg cells. All raising interesting questions about the features of the TME that best support tumor reactive $\mathrm{T}$ cell retention in the tumor.

Published: 4 November 2015

doi:10.1186/2051-1426-3-S2-P235

Cite this article as: Melssen et al:: Cytokines and TLR agonists influence the expression of retention integrins CD49a, CD49b and CD103 by T cells. Journal for ImmunoTherapy of Cancer 2015 3(Suppl 2):P235.
Submit your next manuscript to BioMed Central and take full advantage of:

- Convenient online submission

- Thorough peer review

- No space constraints or color figure charges

- Immediate publication on acceptance

- Inclusion in PubMed, CAS, Scopus and Google Scholar

- Research which is freely available for redistribution
() Biomed Central 